ARTICLE

Received 30 Jul 2015 | Accepted 22 Dec 2015 | Published 26 Jan 2016

DOI: $10.1057 /$ palcomms.2015.46

OPEN

\title{
Climate change, the Great Barrier Reef and the response of Australians
}

Jeremy Goldberg 1,2, Nadine Marshall ${ }^{2,3}$, Alastair Birtles ${ }^{1}$, Peter Case ${ }^{1,4}$, Erin Bohensky², Matt Curnock ${ }^{2}$, Margaret Gooch ${ }^{5,6}$, Howard Parry-Husbands ${ }^{7}$, Petina Pert ${ }^{8,9}$, Renae Tobin ${ }^{3,10}$, Christopher Villani ${ }^{7}$ and Bernard Visperas ${ }^{7}$

\begin{abstract}
Inspiration, aspirations, attitudes, and perception of threats play a pivotal role in the way that individuals associate themselves with natural environments. These sentiments affect how people connect to natural places, including their behaviours, perceived responsibility, and the management interventions they support. World Heritage Areas hold an important place in the lives of people who visit, aspire to visit, or derive a sense of security and well-being from their existence. Yet, the connection between people and special places is rarely quantified and policymakers find it difficult to incorporate these human dimensions into decision-making processes. Here we describe the personal concern and connection that Australians have with the Great Barrier Reef and discuss how the results may help with its management. We utilize a statistically representative sample of Australian residents $(n=2,002)$ and show empirically that climate change is perceived to be the biggest threat to the Great Barrier Reef, and that the Great Barrier Reef inspires Australians, promotes pride, and instills a sense of individual identity and collective responsibility to protect it. An increased understanding of the high levels of personal connection to iconic natural resources may help managers to enhance public support for protecting climate-sensitive systems within Australia and around the world.
\end{abstract}

\footnotetext{
${ }^{1}$ College of Business, Law and Governance, James Cook University, Townsville, Australia ${ }^{2}$ CSIRO Land and Water Flagship, Townsville, Australia ${ }^{3}$ College of Marine and Environmental Sciences, James Cook University, Townsville, Australia ${ }^{4}$ School of Business, University of the West of England, Bristol, UK ${ }^{5}$ Great Barrier Reef Marine Park Authority, Townsville, Australia ${ }^{6}$ The Cairns Institute, Cairns, Australia ${ }^{7}$ Pollinate, Sydney, Australia ${ }^{8}$ CSIRO Land and Water Flagship, Cairns, Australia ${ }^{9}$ James Cook University, College of Marine and Environmental Sciences, Cairns, Australia ${ }^{10}$ Centre for Sustainable Tropical Fisheries and Aquaculture, James Cook University, Townsville, Australia
} 


\section{Introduction}

W

idely regarded as the most extraordinary places on the planet, World Heritage Areas are important icons that possess an exceptional cultural and/or natural significance that transcends national boundaries and merits protection for the international community (United Nations Educational, 1972). However, climate change impacts and economic development are affecting the environmental and social systems (GBRMPA, 2009; Cardinale et al., 2012) associated with World Heritage Areas, including the benefits derived from these areas such as quality of life, spirituality, and recreational opportunities (Corvalan et al., 2005; Adger et al., 2013). While the preservation of the "outstanding universal value" of World Heritage Areas is an obligation of governments seeking to maintain the designation and associated benefits derived from World Heritage status, the resource management response at many locations has been insufficient (Badman et al., 2009). A lack of trust between stakeholders (Gragson and Grove, 2006), conflicts of interest between short- and long-term decision making, and misunderstandings about the associated social, economic and human dimensions (Hughes et al., 2010) can threaten the international status of these Areas, prompting governments to revisit the benefits that can be derived from these places to better manage conflict between stakeholders. Natural resource managers, that is, individuals who develop conservation policies, plans and projects that help people interact with the environment in an ecologically sustainable manner, have thus sought new ways to understand the role of World Heritage Areas in the lives of the community and to promote natural resource conservation while concurrently facilitating the social and economic benefits provided by these special areas (Dobbs et al., 2011).

Crucial to the process of managing international icons is the incorporation of the human dimension into management at local, regional and international scales (Lal et al., 2002). However, an ongoing lack of understanding about the connection that people have with World Heritage Areas, among other factors such as lack of adequate resources, occasionally inhibits the integration of the human dimension into decision making related to natural resource management. Consequently, at some iconic World Heritage sites such as the Great Barrier Reef, community stewardship may be at risking of failing (Scheffer et al., 2015). Although officials are often determined to incorporate evidence-based policy, decisions that balance environmental considerations with socio-economic concerns remain thin on the ground (Juntti et al., 2009) and many environmental policies are developed with a lack of scientific and research evidence (Owens et al., 2006). The integration of social science is crucial to develop new partnerships, divergent thinking, and meaningful contributions to research (Viseu, 2015) and resource management.

The aim of this study was to examine the connection that people have with an iconic place, with the intention that the insights obtained could be used to support management and improve decision-making processes. Clarifying the perceptions that underlie and affect this connection is a crucial first step. We refer specifically to the case of the Great Barrier Reef and build upon the findings of Wynveen et al. (2012), who called for research describing the meanings that more and different types of stakeholders ascribe to the Great Barrier Reef. Such meanings are particularly important as a greater concern and acknowledgement of stakeholder interests may help build institutional trust in management agencies (Wynveen and Sutton, 2015). The incorporation of stakeholder attitudes and perceptions into planning is thus vital for the management of natural resources (Larson et al., 2013), increasing the likelihood of successful and sustainable conservation activities (McCook et al., 2010).

\section{Theoretical background: why places matter to people}

There is a need to better understand the role that nature plays in the lives of people, including concepts such as resource condition and aesthetics (Larson et al., 2013). In a recent review of 40 years of literature, Lewicka (2011) noted that people feel attached to a place for a variety of reasons including social factors, religious symbolism, physical assets, recreational options, and economic and emotional connections. This attachment can influence perceptions of the environment, including risk, emotional bonds with nature and the use of public spaces (Scannell and Gifford, 2010). Thus, conceptualizations of place attachment consider multiple underlying dimensions of the human-place bond, providing a general representation of why stakeholders value a landscape (Wynveen and Kyle, 2015). As people recognize more and stronger meanings related to a place, their attachment to that place increases (Wynveen et al., 2012). This attachment can take the form of symbolic or socially constructed attributes of places and may influence individual evaluations of change, including how people choose to support or oppose environmental decision making (Devine-Wright, 2009) such as renewable energy projects (Devine-Wright and Howes, 2010).

Disconnection from nature is central to ongoing socioecological crises (Zylstra et al., 2014), and understanding the level of connection between people and iconic places may provide opportunities to enhance public support for managing climatesensitive systems such as the Great Barrier Reef (Johnson and Marshall, 2007). One way to understand stakeholder attitudes towards a natural environment is to document the meanings they associate with that setting (Wynveen et al., 2010). Place meanings can be explored in large groups of respondents via close-ended survey items, offering a broad understanding that can provide insight into why places are important to people (Wynveen and Kyle, 2015). Following a multi-disciplinary review of the literature and discussions with local resource managers, we propose that this connection can partially be described by assessing the (1) Inspiration, (2) Aspirations, (3) Personal connection and attitudes, and (4) Perceptions of threats in relation to these special areas.

Australia's natural surroundings have long been a source of inspiration and the connection they provide can play a major role in influencing environmental attitudes (Curtis, 2009). Inspiration is a broad yet familiar emotional construct used to enhance programmes in various disciplines such as business (Souitaris et al., 2007), management (Dess and Picken, 2000) and education (Tjas et al., 1997). Importantly, inspiration implies motivation, including the ability to energize and direct behaviour (Elliot, 1997). Although the natural world is capable of evoking an inspiration that is both motivational and energizing, little attention has been given to understanding the impact of this inspiration and where the motivation is directed (Thrash and Elliot, 2003). In other words, an important knowledge gap exists between understanding where inspiration arises and how that inspiration is utilized.

Aspirations to visit are important to include in a description of the human dimension of World Heritage Areas because visitation influences individual knowledge and attitudes about a location, including the perceptions of social and environmental problems within that setting (Manning et al., 2000). Aspirations to visit protected areas have steadily increased in recent decades (Ham et al., 2009) and these visits influence individual knowledge and attitudes about the locations, including the perceptions of social and environmental problems within that setting (Manning et al., 2000). Personal experience also helps to inform perceptions of risk, awareness and behaviours (Weinstein, 1989). Furthermore, the level of connection that one feels towards a place may influence the development of pro-environmental behaviours 
(Vaske and Kobrin, 2001) such as those that maintain or enhance valued attributes of that setting (Stedman, 2002). For example, people are more willing to fight to protect places they are closely associated with and that they perceive to be in less-thanoptimal condition (Stedman, 2002). Thus, personal experiences with nature can shape opinions about resource protection as well as influence behaviours taken in response to perceived environmental degradation (Devine-Wright and Clayton, 2010).

Understanding how and why an individual connects with a place is potentially an important concern for conservation (Halpenny, 2010), particularly because of influences on social resilience and adaptive capacity. For example, resource-dependent industries such as farmers along the Great Barrier Reef will be required to adapt to a range of climate risks to maintain viable businesses (Marshall et al., 2012). Transformations initiated by threats to local socio-ecological systems are analogous to the situation required to initiate pro-conservation behaviours among members of the general public. That is, if a small subgroup of members of the public (that is, farmers) can demonstrate transformative capacity through a change in behaviour, it may be possible for others as well. Thus, the role of attitudes in mediating behaviours towards the natural world has important practical implications for the development of mechanisms that can foster protective environmental policies (Clayton and Opotow, 2003). From a broader standpoint, the public must transition away from harmful and unsustainable environmental practices to help protect the Great Barrier Reef from climate change (Beeden et al., 2014).

Attitudes are particularly relevant to consider because they affect behaviour (Armitage and Conner, 2001) and environmental attitudes, in particular, influence individuals' environmental behaviours (Kaiser et al., 1999). People connect with special places, and personal experiences and links with nature can affect resource protection, including the development of pro-environmental behaviours taken in response to perceived environmental threats (Vaske and Kobrin, 2001). As attitudes can shape the individual decision making and behavioural response (Lindell and Perry, 2012), perceptions of environmental risk are a key component of behavioural intentions to address associated environmental issues (O'Connor et al., 1999). For example, residents living near the Great Barrier Reef differ in their attitudes about climate change (Tobin et al., 2014); some recognize the importance of taking action or feel morally obligated to act, while others are less concerned (van Riper et al., 2012). Documenting and analysing these individual attitudes is important for developing appropriate solutions to threats to the Great Barrier Reef such as climate change (Ehrlich and Kennedy, 2005), particularly as attitudes help people perceive and evaluate the consequences of undertaking a behavior (Vallerand et al., 1992).

Environmental threats, and the attitudes that individuals associate with them, increasingly impact the general public (Schwartz et al., 1985) as well as the ongoing sustainability measures (Steg and Vlek, 2009) and environmental policies (Wandersman and Hallman, 1993) that affect them. Perceptions of environmental threats not only correlate with behaviour (Seguin et al., 1998), but they also influence the expected collective benefits of taking action (Lubell, 2002). That is, people who perceive that certain activities threaten the environment are more likely to take action to address those threats (Perkins, 2010), thus ensuring long-term sustainability. Individual perceptions offer insights into existing behaviours as well as potential new behaviours that address climate change impacts on World Heritage Areas and other iconic places (van Riper et al., 2012). Thus, individual attitudes related to environmental threats are important attributes for managers to consider (Csutora, 2012).

\section{Methods}

Survey design. Survey questions were developed by the Commonwealth Scientific and Industrial Research Organisation in consultation with the Great Barrier Reef Marine Park Authority and James Cook University. Survey questions were developed to quantify attributes of the social context most relevant to resource management. Where possible, questions were derived from previous surveys administered within the region. Survey questions were initially workshopped and sent out for review to researchers and government end users for refinement and endorsement. Survey questions were also pilot-tested with University students and colleagues. Pollinate, a market research firm based in Sydney, Australia, was commissioned to conduct the study. Since 2007, Pollinate has conducted biannual surveys of more than 20,000 Australians via its "Pulse Omnibus Survey", an ongoing, representative market monitor dedicated to understanding community attitudes towards the environment and associated consumer behaviours. Although additional research methods such as qualitative interviews have proven useful in exploring community perceptions of coral reefs (Mohamed, 2012) as well as behaviours taken in response to climate change (Bohensky et al., 2012), these methods and research questions were beyond the scope of this study. Here, we document a nationally representative perspective of what Australians think about the Great Barrier Reef.

Survey administration. An online questionnaire was conducted by Pollinate, drawing on a representative sample (that is, stratified by age, gender and location) of 2,002 Australian residents recruited from a research panel of more than 180,000 residents. Participation in these panels was voluntary and members joined through certified recruiting partners via a double opt-in registration process. Panel recruitment and sampling methods were in line with specified quotas that were nationally representative of the Australian population. Four areas were explored that are proposed to constitute the connection that people may have with special places:

- Inspiration-Twelve Australian icons, both natural and manmade, were randomly ordered and provided to respondents to select and rank the three most inspiring icons. Among the remaining nine icons, respondents were asked whether each was "inspiring", "not inspiring", or "don't know" (Fig. 1).

- Aspiration-Respondents were asked to state whether they had visited the Great Barrier Reef in the last 12 months, visited the Great Barrier Reef but not in the last 12 months, have never visited the Great Barrier Reef but would like to at some stage, or have never visited the Great Barrier Reef and do not intend to do so.

- Personal connection and attitudes-Respondents were provided with eight randomly ordered statements reflecting their personal connection to, and attitudes about the Great Barrier Reef. They were asked to rate their level of agreement or disagreement on a 10 -point scale where $1=$ very strongly disagree and $10=$ very strongly agree (Fig. 2).

- Perception of threats-Respondents were given a list of 13 randomly ordered threats to the Great Barrier Reef and asked to rank the level of threat on a 10 -point scale, where 1 was equivalent to "not at all threatening" and 10 was equivalent to "extremely threatening" (Fig. 3).

Survey analysis. Survey data were coded and analysed using Q, a qualitative analysis software programme specifically designed for use with large datasets related to market research. We tried to provide a simple and straightforward analysis of the data and did not test the influence of place on the individual variables. Consequently, as only raw data were presented, the data were untreated and, thus, control variables were not applicable in this instance. The survey sample included respondents in all major metropolitan and capital cities, including rural and remote areas throughout Australia. Just over half were female (51\%). Most respondents were employed, either full-time $(35 \%)$ or part-time $(21 \%)$, with the remaining respondents being students, unemployed, retired, or focused on home duties. Many respondents had some University education (32\%) or had studied at a technical institution or completed an apprenticeship (27\%). Respondents' annual incomes were dispersed, with about $60 \%$ earning less than US\$100,000 and $27 \%$ earning less than $\$ 50,000$ per annum.

\section{Results and discussion}

The connection that people have with the Great Barrier Reef. We present the case of the Great Barrier Reef, one of the most iconic and famous ecosystems in the world, and the first coral reef to be established as a World Heritage Area. The Great Barrier Reef extends over $344,400 \mathrm{~km}^{2}$, contains nearly $10 \%$ of the coral reef area in the world, and is home to thousands of different species of plants and animals (GBRMPA, 2009). Despite 40 years of sustained management, the Great Barrier Reef has lost half of its live coral cover in the last 27 years (De'ath et al., 2012), and a 2014 evaluation by the Great Barrier Reef Marine Park Authority (the federal government agency tasked with managing the Great Barrier Reef) 


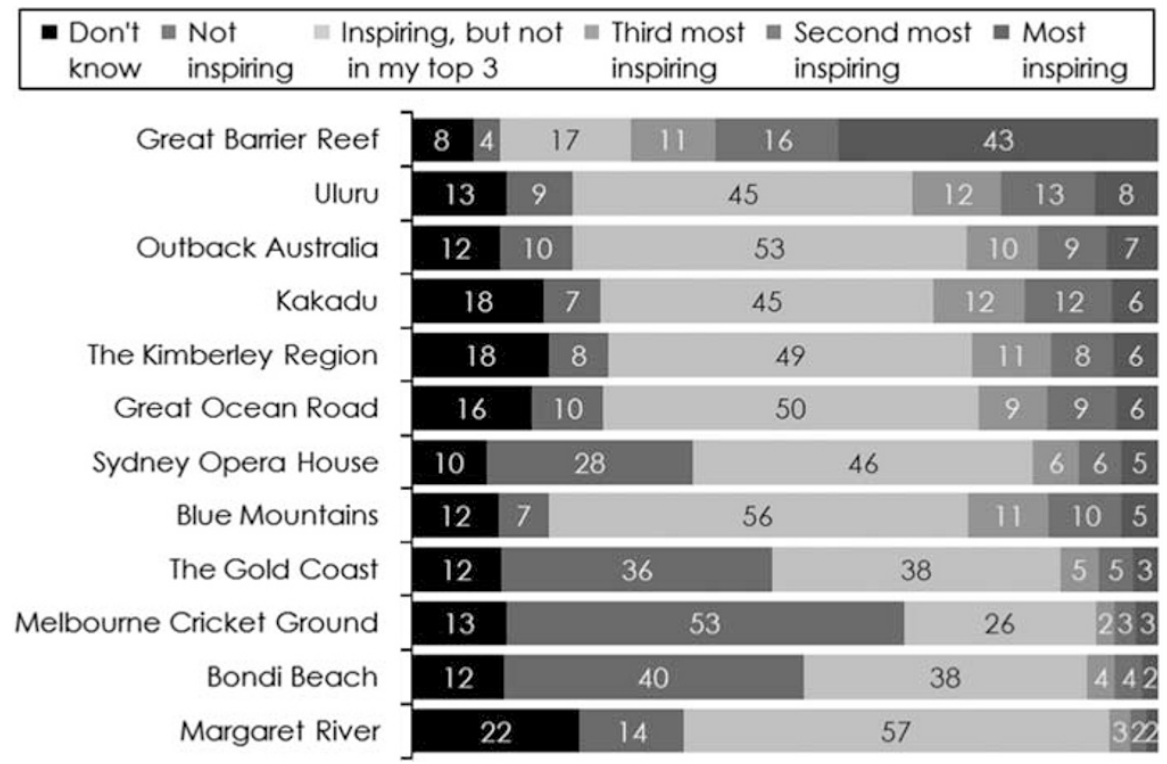

Figure 1 | Perceived inspiration related to 12 popular Australian natural and cultural icons. The 2,002 survey participants were asked to evaluate the inspiration derived from each of 12 national icons. They ranked their top three most inspiring icons, and then assessed the remaining nine as either "inspiring", "not inspiring", or "don't know". The numbers represent the proportion of respondents within each category.

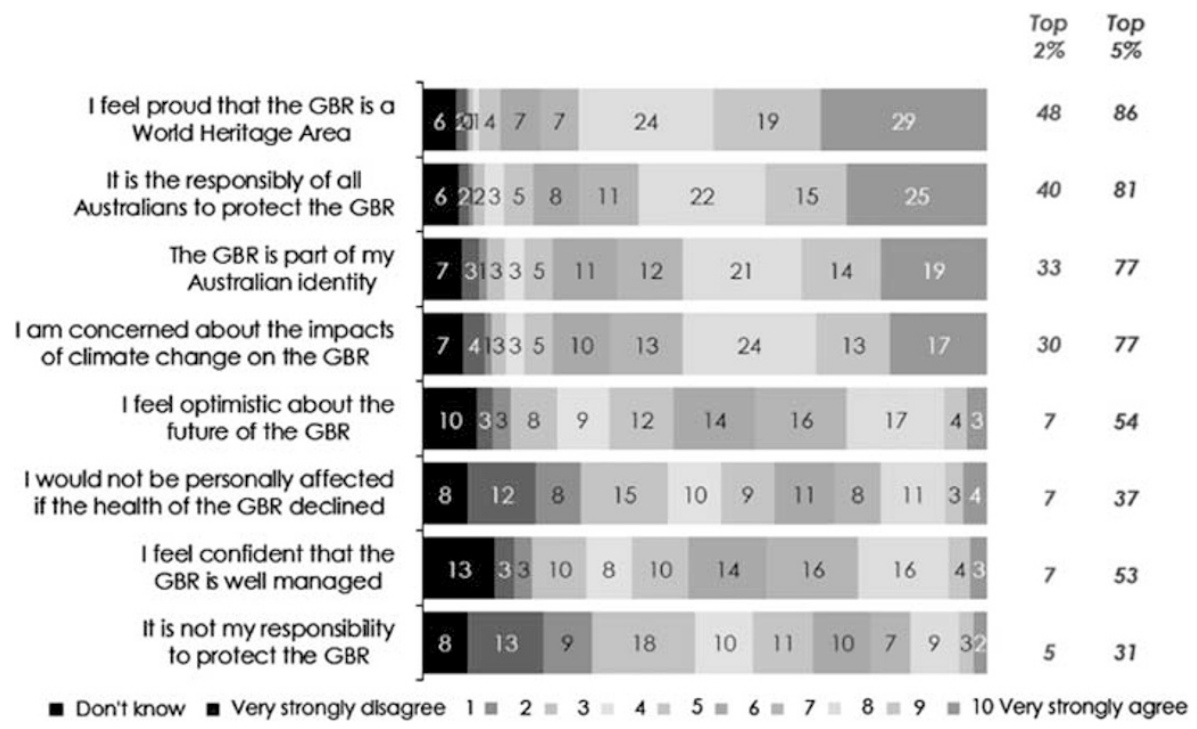

Figure 2 | Respondent attitudes about the Great Barrier Reef (GBR) as scored on a 10-point scale (1 = very strongly disagree and $10=$ very strongly agree). The "Top $2 \%$ " refers to the percentage of respondents who selected a $9 / 10$ or $10 / 10$. The "Top $5 \%$ " refers to the percentage of respondents who agreed with each statement (that is, selected a score of $6,7,8,9$ or 10).

determined that the long-term outlook for the Great Barrier Reef was "poor, and getting worse" (GBRMPA, 2014). Climate change is the most severe threat to the Great Barrier Reef (GBRMPA, 2014) and is projected to lead to a greater prevalence of coral bleaching and disease (Beeden et al., 2012) and changes to the abundance and distribution of marine species (GBRMPA, 2007).

Effectively managing climate change impacts is crucial to ensure the long-term survival of the Great Barrier Reef (GBRMPA, 2009), and if the Great Barrier Reef is to be adequately managed into the future, substantial political attention will be required and considerable resources will need to be invested. The support of the public will be paramount. Targeted communication and social change strategies at both small and large scales will be necessary to transition stakeholders towards a sustainable future (Jamal et al., 2015). This transition must include a variety of individual and collective actions, including the use of renewable energies and more efficient land management practices that reduce coastal pollution. However, relatively little is known about the connection that Australians have with the Great Barrier Reef or what support they have for its management. Although some studies have documented regional perceptions (Nilsson et al., 2010, Sutton and Tobin, 2011, van Riper et al., 2012), there is limited data available from a national Australian perspective. Information is especially lacking about the personal concerns that people have for the Great Barrier Reef and their perceptions of responsibility to protect it. Understanding how Australians feel about the Great Barrier Reef, and what they think of the threats and ongoing management, offers insights into the types of regulations and policies they may support (Hughes et al., 2007, van Riper et al., 2012). 


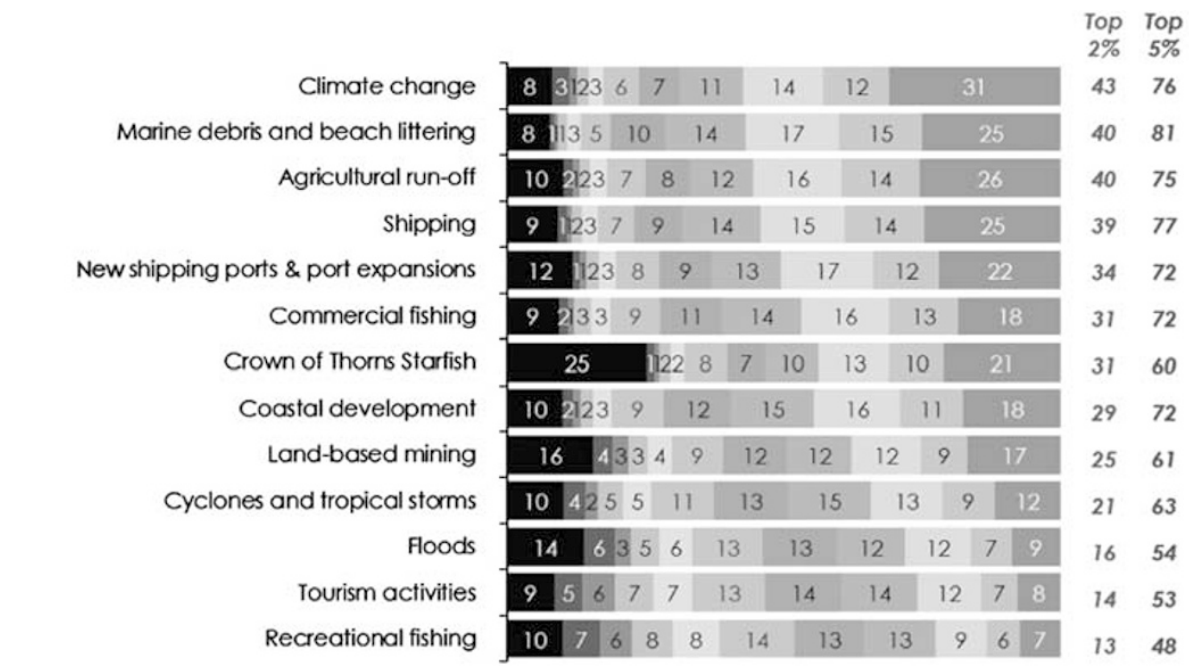

- Don't know | Not at all threatening $1=2=3=4=5=6=7=8=9$ || Extremely threatening 10

Figure 3 | Respondent perceptions of threats to the Great Barrier Reef as scored on a 10-point scale $(1=$ not at all threatening and $10=$ extremely threatening). The "Top $2 \%$ " refers to the percentage of respondents who selected a $9 / 10$ or $10 / 10$. The "Top $5 \%$ " refers to the percentage of respondents who selected a score of $6,7,8,9$ or 10 .

Australians have a strong connection with the Great Barrier Reef, including the inspiration they derive from it. Australians were strongly inspired by the Great Barrier Reef, with $43 \%$ of people in this study listing it as the most inspiring Australian icon, more than five times the level of the second most inspiring icon, Uluru (8\%; Fig. 1). In additional, $88 \%$ of respondents believed the Great Barrier Reef was inspiring, and 71\% included the Great Barrier Reef in their list of the top three most inspiring Australian icons. This collective inspiration may suggest the existence of a widespread and shared emotional connection that could be utilized in profound ways, fostering political support for resource protection, for example, or stimulating resource managers to act boldly in addressing the threat of climate change. It is likely that decision makers have been unable to fully and formally utilize this connection, and that quantifiable evidence may hopefully encourage a more intrepid decision-making process, particularly with respect to climate change.

Millions of Australians have had a direct experience with the Great Barrier Reef. Results from this study suggest that $44 \%$ of Australians have visited the Great Barrier Reef and 8\% visited recently, that is, within a year before survey. Nearly half of the respondents (49\%) had never been to the Great Barrier Reef but would like to at some stage, while $7 \%$ had never been and do not intend to visit the Great Barrier Reef. People want to experience the Great Barrier Reef and when doing so, they indirectly provide considerable support to the regional economy. Tourism activities on the Great Barrier Reef contribute 5.2 billion dollars to Australia's economy each year, including approximately 64,000 full-time jobs (Deloitte Access Economics, 2013). Visits to the Great Barrier Reef also affect the way that Australians feel about it, as people who visit the Great Barrier Reef are more connected to it (Goldberg et al., 2014) and express greater concern about its management (Moscardo, 2008). Simply aspiring to visit the Great Barrier Reef has also been shown to have profound effects. Individuals planning to visit the Great Barrier Reef have a correspondingly higher desire to protect it than those who do not wish to visit (Rolfe and Windle, 2012).

The Great Barrier Reef is part of Australian society, influencing how individuals identify themselves and how they feel about the natural world around them. We found, for example, that $77 \%$ of respondents felt the Great Barrier Reef was part of their identity as Australians (Fig. 2). Pride and feelings of responsibility are also important indicators of the connection that may exist between people and special places. Eighty-six percent of Australians in this study were proud that the Great Barrier Reef is a World Heritage Area, and most agreed that it was the responsibility of all Australians to protect it $(81 \%)$, while $61 \%$ believed it was their individual responsibility to protect the Great Barrier Reef. This connection may support a widely recognized-but as yet undocumented and therefore underutilised - sentiment that there is a social norm around appreciating and protecting the Great Barrier Reef (Cialdini and Goldstein, 2004), that is, protecting the Great Barrier Reef is part of what it means to be Australian or, conversely, that degradation of the Great Barrier Reef is "un-Australian" (Phillips and Smith, 2000). Iconic ecosystems like the Great Barrier Reef are much more than just a place, an economic incentive or a tourist attraction. Rather, our results suggest that they are a source of inspiration and pride, as well as a key contributor to personal identity that also encourages collective responsibility. As such, iconic ecosystems may have the potential to unify seemingly disparate factions of a population around a common goal, for example, the long-term management and preservation of an internationally significant natural resource.

Many Australians, regardless of where they live, suggested that they will be impacted by a decline in the condition of the Great Barrier Reef. Our results showed that $54 \%$ of Australians would be personally affected if the health of the Great Barrier Reef declined and $77 \%$ were concerned about the impacts of climate change on the Great Barrier Reef (Fig. 2). These findings offer an opportunity to highlight and promote widespread public agreement on climate change. Leveraging these similar individual attitudes into a cohesive collective may affect political will around the management of the Reef, supporting new and improved resource management approaches such as the recently declared ban on the disposal of capital dredge material in the Great Barrier Reef Marine Park. Such action may be well aligned with public concerns as just $53 \%$ of Australians in this study were confident that the Great Barrier Reef is well managed and 54\% were optimistic about its future. As such, social and environmental impacts that affect the Great Barrier Reef, while potentially considerable, are also significant opportunities to unify individuals, 
to reconsider ecosystem use, to reframe environmental impacts as personal impacts, and to initiate change, both individual and collective (Perry et al., 2010). If individuals are concerned about the threats to an important icon that they are personally connected to, there is a strong potential to utilize this relationship to encourage a responsive political response (Axelrod and Lehman, 1993). We suggest, like others, that the relationships between individuals and environments that make an ecosystem iconic (that is, an inspirational environment, high personal connection, a strong aspiration to visit and protect it, and so on) can be leveraged to help conserve its associated iconic resources (Reser and Bentrupperbaumer, 2005).

Australians believe that climate change is the biggest threat to the Great Barrier Reef, with responses in this study being strongly skewed towards an extreme threat rather than a minor threat (Fig. 3). Overall, 89\% of Australians believed that climate change is a threat to the Great Barrier Reef. These findings are congruent with the widely recognized scientific opinion that climate change is the biggest long-term threat to coral reefs around the world, including the Great Barrier Reef (GBRMPA, 2009). However, translating these attitudes about climate change into a pragmatic community response that benefits local ecosystems will require a rapid and widespread reaction, both at the individual and societal level (Whitmarsh and Lorenzoni, 2010). For example, there is an immediate need to transition to renewable energies to curb the effects of climate change on marine tourism enterprises (Odeku, 2013). Unfortunately, social change is notoriously problematic to create, particularly with respect to climate change policy. Societal innovation may require the erosion of the status quo, new social arrangements for crafting public policy, and radical innovations that disrupt existing research paradigms (Shove, 2010). While difficult, initiatives led by government or industry may provide the initiative required to foster widespread behaviour change needed to address pressing environmental threats such as climate change (Ockwell et al., 2009, Zeppel, 2012).

\section{Incorporating the human dimension into resource management}

The iconic status and precarious future of the Great Barrier Reef appears to affect a large majority of the Australian population. Our results suggest that the Great Barrier Reef is one of Australia's most inspiring and most personally significant national icons. It is also among the most vulnerable, and Australians overwhelmingly recognize that there are many diverse and severe threats to the Great Barrier Reef, particularly climate change. These results do not directly assess public support for management or legislation, yet they indicate that Australians may be open to stronger policies for protecting the Great Barrier Reef, particularly those that are aligned with their own beliefs (Ward and van Vuuren, 2013). While some of our findings address novel areas of enquiry, such as the inspiration derived from Australian icons, other results support previous studies highlighting climate change awareness within Australian communities (Nilsson et al., 2010) and concern about climate change impacts along the Great Barrier Reef (Sutton and Tobin, 2011; van Riper et al., 2012).

An exploration of the national psyche provides preliminary context for assessing support for existing management policies and ongoing communication and engagement frameworks. For example, the broad recognition that climate change is a major threat to the Great Barrier Reef may instil greater confidence in managers and policymakers to engage the public in discussions about a more robust management response. The Great Barrier Reef Marine Park Authority has proactively initiated a variety of forward-thinking projects including a vulnerability assessment and a multi-year action plan to address climate change impacts on the Great Barrier Reef. However, clarifying individual perspectives will help managers to synchronize these outputs with community intentions as well as evaluate the ongoing efficacy of existing arrangements.

The Great Barrier Reef is one of the most widely recognized and valuable ecosystems on the planet, but economic and environmental arguments have not been sufficient to protect it from major threats such as climate change. However, such arguments may be more effective and impactful if they are communicated in a way that reflects the influential attributes that connect individuals to the Great Barrier Reef. Effective resource management depends upon the policies and regulations in place, but also upon how resource users perceive environmental conditions, regulations and management effectiveness. A strong majority of Australians are deeply concerned about and connected to the Great Barrier Reef, and these relationships may provide the necessary leverage to facilitate community support for enhanced management and protection of the Great Barrier Reef. The socioecological impact resulting from the loss of the Great Barrier Reef would be inconceivably large, but so too is the existing opportunity to galvanize the social and cultural values it instils in us to ensure its future preservation.

\section{References}

Adger W N, Barnett J, Brown K, Marshall N and O'brien K (2013) Cultural dimensions of climate change impacts and adaptation. Nature Climate Change; 3: $112-117$.

Armitage C J and Conner M (2001) Efficacy of the theory of planned behaviour: A meta-analytic review. British Journal of Social Psychology; 40 (4): 471-499.

Axelrod L J and Lehman D R (1993) Responding to environmental concernsWhat factors guide individual action. Journal of Environmental Psychology; 13 (2): 149-159.

Badman T, Bomhard B, Fincke A, Langley J, Rosabal P and Sheppard D (2009) World Heritage in Danger. IUCN World Heritage Studies, Gland, Switzerland, International Union for Conservation of Nature, p. 50.

Beeden R, Maynard J, Johnson J, Dryden J, Kininmonth S and Marshall P (2014) No-anchoring areas reduce coral damage in an effort to build resilience in Keppel bay, southern Great Barrier Reef. Australasian Journal of Environmental Management; 21 (3): 311-319.

Beeden R, Maynard J A, Marshall P A, Heron S F and Willis B L (2012) A framework for responding to coral disease outbreaks that facilitates adaptive management. Environmental Management; 49 (1): 1-13.

Bohensky E L, Smajgl A and Brewer T (2012) Patterns in household-level engagement with climate change in Indonesia. Nature Climate Change; 3, 348-351.

Cardinale B J et al (2012) Biodiversity loss and its impact on humanity. Nature; 486 (7401): 59-67.

Cialdini R B and Goldstein N J (2004) Social influence: Compliance and conformity. Annual Review of Psychology; 55 (1): 591-621.

Clayton S D and Opotow S (2003) Identity and the Natural Environment: The Psychological Significance of Nature. MIT Press: Cambridge, MA.

Corvalan C, Hales S and Mcmichael A (2005) Ecosystems and Human Well-Being: Health Synthesis. Millennium Ecosystem Assessment, World Health Organization: Geneva, Switzerland.

Csutora M (2012) One more awareness gap? The behaviour-impact gap problem. Journal of Consumer Policy; 35 (1): 145-163.

Curtis D J (2009) Creating inspiration: The role of the arts in creating empathy for ecological restoration. Ecological Management and Restoration; 10 (3): 174-184.

De'ath G, Fabricius K E, Sweatman H and Puotinen M (2012) The 27-year decline of coral cover on the Great Barrier Reef and its causes. Proc Natl Acad Sci U S A; 109 (44): 17995-17999.

Deloitte Access Economics. (2013) Economic Contribution of the Great Barrier Reef. Great Barrier Reef Marine Park Authority: Townsville, Australia.

Dess G G and Picken J C (2000) Changing roles: Leadership in the 21st century. Organizational Dynamics; 28 (3): 18-33.

Devine-Wright P (2009) Rethinking NIMBYism: The role of place attachment and place identity in explaining place-protective action. Journal of Community \& Applied Social Psychology; 19 (6), 426-441.

Devine-Wright P and Clayton S (2010) Introduction to the special issue: Place, identity and environmental behaviour. Journal of Environmental Psychology; 30 (3): $267-270$ 
Devine-Wright P and Howes Y (2010) Disruption to place attachment and the protection of restorative environments: A wind energy case study. Journal of Environmental Psychology; 30 (3): 271-280.

Dobbs K et al (2011) Developing a long-term outlook for the Great Barrier Reef, Australia a framework for adaptive management reporting underpinning an ecosystem-based management approach. Marine Policy; 35 (2): 233-240.

Ehrlich P R and Kennedy D (2005) Millennium assessment of human behavior. Science; 309 (5734): 562-563.

Elliot A J (1997) Integrating the "classic" and "contemporary" approaches to achievement motivation: A hierarchical model of approach and avoidance achievement motivation In: Maehr M L and Pintrich P R (eds.) Advances in Motivation and Achievement. JAI Press: Greenwich, CT.

GBRMPA. (2007) Great Barrier Reef Climate Change Action Plan 2007-2011. Great Barrier Reef Marine Park Authority: Townsville, Australia.

GBRMPA. (2009) Great Barrier Reef Outlook Report 2009. Great Barrier Reef Marine Park Authority: Townsville, Australia.

GBRMPA. (2014) Great Barrier Reef Outlook Report 2014. Great Barrier Reef Marine Park Authority: Townsville, Australia.

Goldberg J et al (2014) SELTMP 2013: A National Survey of the Great Barrier Reef. CSIRO: Townsville, Australia.

Gragson T L and Grove M (2006) Social science in the context of the long term ecological research program. Society \& Natural Resources; 19 (1), 93-100.

Halpenny E A (2010) Pro-environmental behaviours and park visitors the effect of place attachment. Journal of Environmental Psychology; 30 (4): 409-421.

Ham S, Brown T, Curtis J, Weiler B, Hughes M and Poll M (2009) Promoting Persuasion in Protected Areas: A Guide for Managers Who Want to use Strategic Communication to Influence Visitor Behaviour. CRC for Sustainable Tourism Pty Ltd: Gold Coast, Queensland.

Hughes T P, Graham N A J, Jackson J B C, Mumby P J and Steneck R S (2010) Rising to the challenge of sustaining coral reef resilience. Trends in Ecology of Evolution; 25 (11): 633-642.

Hughes T P et al (2007) Adaptive management of the Great Barrier Reef and the grand canyon world heritage areas. Ambio; 36 (7): 586-592.

Jamal T, Prideaux B, Sakata H and Thompson M (2015) A micro-macro assessment of climate change and visitors to the Great Barrier Reef, Australia. In Vijay Reddy M and Wilkes K (eds.) Tourism in the Green Economy. Routledge: New York, pp. 271-287.

Johnson J E and Marshall P A (2007) Climate Change and the Great Barrier Reef: A Vulnerability Assessment. Great Barrier Marine Park Authority and Australian Greenhouse Office: Townsville, Australia.

Juntti M, Russel D and Turnpenny J (2009) Evidence, politics and power in public policy for the environment. Environmental Science \& Policy; 12 (3): 207-215.

Kaiser F G, Wolfing S and Fuhrer U (1999) Environmental attitude and ecological behaviour. Journal of Environmental Psychology; 19 (1): 1-19.

Lal P, Lim-Applegate H and Scoccimarro M (2002) The adaptive decision-making process as a tool for integrated natural resource management: Focus, attitudes, and approach. Conservation Ecology; 5 (2): 11.

Larson S, De Freitas D M and Hicks C C (2013) Sense of place as a determinant of people's attitudes towards the environment: Implications for natural resources management and planning in the Great Barrier Reef, Australia. Journal of Environmental Management; 117: 226-234.

Lewicka M (2011) Place attachment: How far have we come in the last 40 years? Journal of Environmental Psychology; 31 (3): 207-230.

Lindell M K and Perry R W (2012) The protective action decision model: Theoretical modifications and additional evidence. Risk Analysis; 32 (4): $616-632$.

Lubell M (2002) Environmental activism as collective action. Environment and Behavior; 34 (4): 431-454.

Manning R E, Valliere W, Bacon J, Graefe A, Kyle G and Hennessy R (2000) Use and users of the appalachian trail: A geographic study. Proceedings of the 2000 Northeastern Recreation Research Symposium; 276: 115-120.

Marshall N A, Park S E, Adger W N, Brown K and Howden S M (2012) Transformational capacity and the influence of place and identity. Environmental Research Letters; 7 (3): 034022.

McCook L J et al (2010) Adaptive management of the great barrier reef: A globally significant demonstration of the benefits of networks of marine reserves. Proceedings of the National Academy of Sciences of the United States of America; 107 (43): 18278-18285.

Mohamed M (2012) Changing Reef Values: An Inquiry into the Use, Management and Governances of Reef Resources in Island Communities of the Maldives. University of Canterbury: Christchurch, New Zealand.

Moscardo G (2008) Exploring public awareness of threats to the Great Barrier Reef environment. Interdisciplinary Environmental Review; 10 (1-2): 45-64.

Nilsson J A, Sutton S G and Tobin R C (2010) A Community Survey of Climate Change and the Great Barrier Reef. Marine and Tropical Research Facility Research Report $S$ eries. Marine and Tropical Research Facility: Cairns, Australia.
O'Connor R E, Bord R J and Fisher A (1999) Risk perceptions, general environmental beliefs, and willingness to address climate change. Risk Analysis; 19 (3): 461-471.

Ockwell D, Whitmarsh L and O'neill S (2009) Reorienting climate change communication for effective mitigation forcing people to be green or fostering grass-roots engagement? Science Communication; 30 (3): 305-327.

Odeku K O (2013) On decarbonising tourism: The need to switch to renewable energy. The Journal of Human Ecology; 44 (3): 231-245.

Owens S, Petts J and Bulkeley H (2006) Boundary work: Knowledge, policy, and the urban environment. Environment and Planning C; 24 (5): 633.

Perkins H E (2010) Measuring love and care for nature. Journal of Environmental Psychology; 30 (4): 455-463.

Perry R I, Barange M and Ommer R E (2010) Global changes in marine systems: A social-ecological approach. Progress in Oceanography; 87 (4): 331-337.

Phillips T and Smith P (2000) What is 'Australian'? Knowledge and attitudes among a gallery of contemporary Australians. Australian Journal of Political Science; 35 (2): 203-224.

Reser J P and Bentrupperbaumer J M (2005) What and where are environmental values? Assessing the impacts of current diversity of use of 'environmental' and 'world heritage' values. Journal of Environmental Psychology; 25 (2): 125-146.

Rolfe J and Windle J (2012) Distance decay functions for iconic assets: Assessing national values to protect the health of the great barrier reef in Australia. Environmental \& Resource Economics; 53 (3): 347-365.

Scannell L and Gifford R (2010) Defining place attachment: A tripartite organizing framework. Journal of Environmental Psychology; 30 (1): 1-10.

Scheffer $M$ et al (2015) Creating a safe operating space for iconic ecosystems. Science; 347 (6228): 1317-1319.

Schwartz S P, White P E and Hughes R G (1985) Environmental threats, communities and hysteria. Journal of Public Health Policy; 6 (1): 58-77.

Seguin C, Pelletier L G and Hunsley J (1998) Toward a model of environmental activism. Environment and Behavior; 30 (5): 628-652.

Shove E (2010) Beyond the ABC: Climate change policy and theories of social change. Environment and Planning A; 42 (6): 1273-1285.

Souitaris V, Zerbinati S and Al-Laham A (2007) Do entrepreneurship programmes raise entrepreneurial intention of science and engineering students? The effect of learning, inspiration and resources. Journal of Business Venturing; 22 (4): 566-591.

Stedman R C (2002) Toward a social psychology of place-Predicting behavior from place-based cognitions, attitude, and identity. Environment and Behavior 34 (5): $561-581$.

Steg L and Vlek C (2009) Encouraging pro-environmental behaviour: An integrative review and research agenda. Journal of Environmental Psychology; 29 (3): 309-317.

Sutton S G and Tobin R C (2011) Constraints on community engagement with great barrier reef climate change reduction and mitigation. Global Environmental Change-Human and Policy Dimensions; 21 (3): 894-905.

Thrash T M and Elliot A J (2003) Inspiration as a psychological construct. Journal of Personality and Social Psychology; 84 (4): 871-889.

Tjas K, Nelsen E A and Taylor M (1997) Successful alumni as role models for high school youth. High School Journal; 80 (2): 103-110.

Tobin R et al (2014) The Social and Economic Long Term Monitoring Program (SELTMP) 2013: Recreation in the Great Barrier Reef. Report to the National Environmental Research Program. Reef and Rainforest Research Centre Limited: Cairns, Australia.

United Nations Educational, S. C. O. U. (1972) Convention Concerning the Protection of the world cultural and natural heritage. (Report No. WHC-2001/ WS/2) Paris, France.

Vallerand R J, Pelletier L G, Deshaies P, Cuerrier J P and Mongeau C (1992) Ajzen and Fishbein theory of reasoned action as applied to moral behavior-A confirmatory analysis. Journal of Personality and Social Psychology; 62 (1): 98-109.

Van Riper C J, Kyle G T, Sutton S G, Yoon J I and Tobin R C (2012) Australian residents' attitudes toward pro-environmental behaviour and climate change impacts on the great barrier reef. Journal of Environmental Planning and Management; iFirst article 56 (4): 1-18.

Vaske J J and Kobrin K C (2001) Place attachment and environmentally responsible behavior. The Journal of Environmental Education; 32 (4): 16-21.

Viseu A (2015) Integration of social science into research is crucial. Nature; 525 (7569): 291-291.

Wandersman A H and Hallman W K (1993) Are people acting irrationally? Understanding public concerns about environmental threats. American Psychologist; 48 (6): 681-686.

Ward S and Van Vuuren K (2013) Belonging to the rainbow region: Place, local media, and the construction of civil and moral identities strategic to climate change adaptability. Environmental Communication-A Journal of Nature and Culture; 7 (1): 63-79.

Weinstein N D (1989) Effects of personal experience on self-protective behavior Psychological Bulletin; 105 (1): 31-50. 
Whitmarsh L and Lorenzoni I (2010) Perceptions, behavior and communication of climate change. Wiley Interdisciplinary Reviews-Climate Change; 1 (2): 158-161.

Wynveen C J and Kyle G T (2015) A place meaning scale for tropical marine settings. Environmental Management; 55 (1): 128-142.

Wynveen C J, Kyle G T and Sutton S G (2010) Place meanings ascribed to marine settings: The case of the great barrier reef marine park. Leisure Sciences; 32 (3): 270-287.

Wynveen C J, Kyle G T and Sutton S G (2012) Natural area visitors' place meaning and place attachment ascribed to a marine setting. Journal of Environmental Psychology; 32 (4): 287-296.

Wynveen C J and Sutton S G (2015) Engaging the public in climate change-related pro-environmental behaviors to protect coral reefs: The role of public trust in the management agency. Marine Policy; 53: 131-140.

Zeppel H (2012) Collaborative governance for low-carbon tourism: Climate change initiatives by Australian tourism agencies. Current Issues in Tourism; 15 (7): 603-626.

Zylstra M J, Knight A T, Elser K J and Le Grange L L L (2014) Connectedness as a core conservation concern: An interdisciplinary review of theory and a call for practice. Springer Science Reviews; 2 (1): 119-143.

\section{Data Availability}

The datasets generated and analysed during this study are available in the eAtlas repository: http://seltmp.eatlas.org.au/seltmp/survey-data.

\section{Acknowledgements}

The authors thank Roger Beeden, Paul Marshall, and Lea Scherl for comments and insights leading to the development of this manuscript. This project was supported by CSIRO Land and Water Flagship, the National Environmental Research Program, James Cook University and an International Postgraduate Research Scholarship from James Cook University to J.G.

\section{Additional information}

Competing interests: The authors declare no competing financial interests.

Reprints and permission information is available at http://www.palgrave-journals.com/ pal/authors/rights_and_permissions.html

How to cite this article: Goldberg J, Marshall N, Birtles A, Case P, Bohensky E, Curnock M, Gooch M, Parry-Husbands H, Pert P, Tobin R, Villani C and Visperas B (2016) Climate change, the great barrier reef, and the response of Australians. Palgrave Communications. 2:15046 doi: 10.1057/palcomms.2015.46.

This work is licensed under a Creative Commons Attribution 4.0 International License. The images or other third party material in this article are included in the article's Creative Commons license, unless indicated otherwise in the credit line; if the material is not included under the Creative Commons license, users will need to obtain permission from the license holder to reproduce the material. To view a copy of this license, visit http://creativecommons.org/licenses/by/4.0/ 